\title{
QTL MAPPING OF BROOMRAPE (OROBANCHE CUMANA WALLR.) RESISTANCE IN SUNFLOWER (HELIANTHUS ANNUUS L.) USING GBS-SNPS
}

\author{
Asena Akkose BAYTAR ${ }^{1}$, Ibrahim CELIK ${ }^{2}$, Cafer DOGANLAR ${ }^{3}$, Anne FRARY $Y^{1}$, Sami DOGANLAR ${ }^{1,4^{*}}$ \\ ${ }^{I}$ Izmir Institute of Technology, Department of Molecular Biology and Genetics, Urla, Izmir, TURKEY \\ ${ }^{2}$ Pamukkale University, Cal Vocational School of Higher Education, Department of Plant and Animal \\ Production, Cal, Denizli, TURKEY \\ ${ }^{3}$ Agromar Seed Co., Karacabey, Bursa, TURKEY \\ ${ }^{4}$ Izmir Institute of Technology, Plant Science and Technology Applied Research Center, Izmir, TURKEY \\ *Corresponding author: samidoganlar@iyte.edu.tr
}

Received: 06.07.2021

\begin{abstract}
Broomrape is one of the most important biotic stresses causing serious yield reductions in sunflower. Control of this parasitic plant is difficult and physical and chemical strategies are usually insufficient. Therefore, introduction of genetic resistance to broomrape in sunflower is a key breeding goal. Breeding efforts on broomrape resistance have been conducted for decades, however, new broomrape races, such as race $F$, have emerged and rapidly evolved to be more aggressive and devastating. Although a few quantitative trait loci (QTLs) were identified for race $F$ resistance, none of these loci are suitable for marker assisted selection because of their small phenotypic effects. In the present study, three major QTLs for broomrape race $F$ resistance were identified on LG7, LG11 and LG12 using a high density SNP map constructed with the genotyping by sequencing approach in an intraspecific $F_{2}$ population. The population consisted of 300 individuals derived from a cross between susceptible Helianthus annuus cv. RHA 436 as the recipient parent and resistant $H$. annuus cv. $\mathrm{H08} \mathrm{M} 1$ as the donor parent. Breeder-friendly SNP-based cleaved amplified polymorphic sequence markers were developed for the QTLs. The QTLs and CAPS markers identified in this study will be valuable molecular genetic tools for sunflower breeding.
\end{abstract}

Keywords: Genotyping by sequencing (GBS), molecular breeding, quantitative trait loci (QTL) annotation, single nucleotide polymorphism (SNP)

\section{INTRODUCTION}

Broomrape (Orobanche cumana Wallr./Orobanche cernua Loefl.) is a weedy haloparasitic, nonphotosynthetic plant and is one of the most severe biotic stress factors in sunflower (Helianthus annus L.). Weed management of $O$. cumana is very difficult because it has a wide host range and produces thousands of small, light and easily dispersed seeds that can remain viable for 10 to 20 years (Bulbul et al., 1991). Although several control measures such as herbicide treatment and soil solarization have been developed, the first priority for defense has been genetic resistance against broomrape (Tang et al., 2003). In the 1980s, Vranceanu et al. (1986) identified five physiological broomrape races (A-E) and differentiated the hosts for these races by introgression of dominant resistance genes (Or1, Or2, Or3, Or4 and Or5) from wild Helianthus tuberosus L. into the cultivated sunflower genomic background.

Although these resistance genes have proven effective for many years, selection pressure on broomrape has resulted in the evolution and emergence of new races. A new, more virulent and aggressive race, called $\mathrm{F}$, broke out in some areas of Spain in the mid-1990s and overcame the resistance provided by all five genes (Louarn et al., 2016). Race F has also been observed in Romania, Turkey, Ukraine and Russia with increasing virulence in recent years (Martin-Sanz et al., 2016). Molinero-Ruiz et al. (2014) reported that in Spain the predominant races were $\mathrm{E}$ and $\mathrm{F}$. Race $\mathrm{F}$ has been described as most infective in Spain and has spread to northern areas (Cvejic et al., 2020). Race F has also been reported in Hungary (Molinero-Ruiz et al., 2014). Kaya et al. (2004) stated that the virulence of race $\mathrm{F}$ was higher in Turkey than in other European countries suffering from the same race.

Despite the importance of race $\mathrm{F}$, the molecular genetic basis of resistance has not been conclusively determined. Although inheritance studies reported that race $\mathrm{F}$ resistance was controlled by two epistatic genes (Akhtouch et al., 2002; Velasco et al., 2007), three other studies proposed that resistance was quantitatively 
inherited (Perez-Vich et al., 2004; Louarn et al., 2016; Akhtouch et al., 2016). Pérez-Vich et al. (2004) used a population derived from lines P-96 (resistant) and P-21 (susceptible) to detect QTLs associated with broomrape resistance, and identified six QTLs for race $\mathrm{F}$ resistance on LG1, 4, 5, 13 and 16. Although Akhtouch et al. (2016) identified five QTLs on LG2, 3, 4, 5 and 6 in line K-96; they did not identify all of the same QTLs identified by Pérez-Vich et al. (2004) (those on LG1, 13 and 16). However, both studies reported that the broomrape resistance QTL on LG5 was stable and provided by P-21, not P-96. In another study Louarn et al. (2016), detected 10 QTLs on LG4, 6, 9, 11, 13 and 15 for three stages of race F development. In that study, a QTL region on LG13 which controlled the number of emergences in the field coincided with a QTL mapped by Pérez-Vich et al. (2004). However, all of the loci in these previous studies had minor or moderate effects with maximum percentage of phenotypic variation explained (PVE) of 39\%. In another study, researchers used bulked segregant analysis (BSA) to identify a single marker (ORS683) linked to resistance to race $\mathrm{F}$ and higher on LG3 (Imerovski et al., 2016). The marker was determined to be $1.5 \mathrm{cM}$ from the resistance gene.

A lack of satisfying agreement in the results of the previous QTL mapping studies indicates that resistance is dependent on race, resistance source (donor parent) and even recipient parent. Thus, additional mapping studies using new donor and recipient parent combinations and genomics technologies are essential for a better understanding of broomrape race $\mathrm{F}$ resistance and for efficient sunflower breeding. In the present study we identified QTLs for race F resistance using a SNP based map generated using the genotyping by sequencing (GBS) approach.

\section{MATERIALS and METHODS}

\section{Plant materials}

An intraspecific $F_{2}$ population consisting of 300 individuals generated by Agromar Seed Co. Bursa, Turkey from a cross between susceptible $H$. annuus cv. RHA 436 as recipient parent and resistant $H$. annuus cv. H08 M1 as donor parent was used to test for mapping broomrape resistance.

\section{Broomrape resistance assay}

The parents and $F_{2}$ population were tested for resistance in 2013. Seeds of broomrape were collected from mature plants attached to the roots of sunflowers grown in race $\mathrm{F}$ infected fields in the Thrace region of Turkey in 2012. All plants were grown in small plastic cups $(7 \times 7 \times 8 \mathrm{~cm})$ with $0.28 \mathrm{mg}$ of broomrape seed per $\mathrm{g}$ of soil (Martin-Sanz et al., 2016) placed in the bottom and covered with a mixture of sandy soil, turf and loamy soil (1: 1: 1, v: v: v). Sunflower seeds were planted and grown under controlled conditions at $25^{\circ} \mathrm{C}$ and with $14 \mathrm{~h}$ photoperiod. Thirty-five days after planting, sunflower roots were gently removed from soil and washed. Total broomrape nodules were counted for each plant. Roots with no nodule (0) formation were considered to be resistant and those with nodule $(\geq 1)$ formation were considered to be susceptible (Velasco et al., 2007; Grenz et al., 2008).

\section{Molecular genetic data and QTL mapping}

QTL mapping was performed with a SNP based map covering all linkage groups (LG1 to 17) using a selected subset of the population (95 individuals) based on the best DNA quality and quantity results (data not shown here) from Qubit ${ }^{\mathrm{TM}}$ quantitation assay (Life Technologies) (map and marker details can be found in Celik et al., 2016a). For QTL identification, the CIM (composite interval mapping) method which does both interval and multiple regression mapping with automatic forward cofactor selection was used with QGene 4.0 software (Joehanes and Nelson, 2008). The genome-wide critical threshold value for type I error rate $(\alpha=0.01)$ was calculated after 1,000 random permutations of QTL analysis (Churchill and Doerge, 1994). Resistant and susceptible plants were scored as 0 and 1 , respectively.

\section{Development of SNP based CAPS assay}

A cleaved amplified polymorphic sequence (CAPS) marker was developed for each QTL for verification in 43 resistant $F_{6}$ individuals derived from the $F_{2}$ population. CAPS

Designer (https://solgenomics.net/tools/caps_designer/caps_input.pl ) and BatchPrimer3 (You et al., 2008) were used for identification of restriction enzymes and to design primers, respectively. Genomic DNA isolation and PCR analysis were conducted as described by Celik et al. (2016b).

\section{Annotation of QTLs}

The study also aimed to identify candidate genes that might be responsible for race $\mathrm{F}$ resistance in the identified QTL regions. Therefore, 61,175 unigene transcripts [PUTs (PlantGDB-derived Unique Transcripts)] were downloaded from the Plant GDB database (Dong et al., 2004).

(http://www.plantgdb.org/download/download.php?dir=/S equence/ESTcontig/Helianthus annuus). These sequences were aligned to the three identified QTLs using Spidey software with default parameters and the plant gene model (http://www.ncbi.nlm.nih.gov/spidey/). All of the transcripts that mapped on the QTLs were functionally annotated using Blast2GO software (Conesa et al., 2005). In addition to the transcripts, two candidate genes (RSG3-301 and HaGSL1) with function in gene for gene interactions between weeds and hosts were used in physical mapping (Li and Timko, 2009).

\section{RESULTS}

\section{Broomrape resistance assay}

A total of 300 individuals of the $H$. annuus cv. RHA 436 (susceptible) and H08 M1 (resistant) $\mathrm{F}_{2}$ mapping population were tested for broomrape race $\mathrm{F}$ resistance. The trait segregated in the mapping population. While 180 $(60 \%)$ individuals were susceptible, $120(40 \%)$ individuals 
were resistant. This segregation pattern most closely fit a recessive epistasis gene action model (9:7 segregation) as confirmed by a Chi square goodness of fit test $(\mathrm{p}=0.34)$.

\section{QTL mapping}

A composite interval mapping (CIM) approach was used to map the QTLs for resistance to broomrape race F. The SNP markers developed by GBS (genotyping by sequencing) reported by Celik et al. (2016a) were used in the analysis. As a result, three QTLs, or7.1, or 11.1 and or12.1 explaining 41 to $49 \%$, of the phenotypic variation were identified on linkage groups LG7, LG11 and LG12, respectively, based on a logarithm of odds (LOD) threshold ( $\mathrm{p}<0.05)$ value of 8.3 as calculated with 1,000 permutations (Table 1). As expected, alleles of the $H$. annuus cv. H08 M1 (the resistant parent) were associated with increased resistance scores for all QTLs.

\section{SNP based CAPS assay}

The identified QTLs were verified in an $\mathrm{F}_{6}$ population derived from the original $\mathrm{F}_{2}$ population. SNPs specific for each resistance QTL were converted to CAPS assays (Table 1). All primers produced clear PCR products. Digested PCR products enabled discrimination of resistance and susceptibility alleles of the QTLs in all individuals (Table 2). Most of the resistant individuals (40 plants, 93\%) contained at least one resistance QTL. Thus, the study showed that only one of the three newly identified QTLs is sufficient to confer resistance to broomrape race $\mathrm{F}$.

\section{Annotation of QTLs}

The identified QTLs were annotated in an attempt to find the genes related to disease response. To achieve this aim, peak positions of the QTLs based on the physical map were annotated. As a result, 161, 162 and 96 transcripts were mapped to the or7.1, or11.1 and or12.1 QTL regions, respectively. One transcript that mapped to or7.1 was annotated as a LURP-one-related 10-like gene which has a defense response function (Knoth and Eulgem, 2008). The rest of the transcripts had cellular functions such as protein, GTP and DNA binding which were not specifically related to the expected disease response. Also candidate genes (RSG3-301 and HaGSL1) were not mapped to any QTLs in the present study.

\section{DISCUSSION}

\section{Broomrape resistance assay}

Segregation of resistance in the $\mathrm{F}_{2}$ population, derived from $H$. annuus cv. RHA 436 as recipient parent and $H$. annuus cv. H08 M1 as donor parent, fit a complementary gene action model involving two genes. This segregation ratio was the same as was observed in another $F_{2}$ population derived from a cross between the resistant donor parent $H$. annuus cv. RA1 and the same recurrent parent $H$. annuus cv. RHA436 [182 (60\%) and $122(40 \%)$ individuals found to be susceptible and resistant, respectively] (unpublished data). However, the results conflicted with previous studies that reported that resistance for race $\mathrm{F}$ was controlled by two recessive genes (or6 and or7) (Akhtouch et al., 2002; Fernandez-
Martinez et al., 2004), one recessive gene on LG3 harboring the closest marker ORS683 (Imerovski et al., $2016)$ or two dominant-recessive epistatic genes (Akhtouch et al., 2016). Duriez et al. (2019) used map based cloning and reported that the Or7 gene (HaOr7) is an LRR receptor like membrane protein that gives resistance to race $\mathrm{F}$. The HAOR7 protein functions in signal transduction through its intracellular kinase domain. In resistant plants, the HaOr7 gene leads to incomplete attachments and restrains the connection between $O$. cumana and the plant root's vascular system. Martin-Sanz et al. (2020) studied sunflower broomrape resistance to race $\mathrm{F}$ and $\mathrm{G}$ and reported that the resistance gene $O r_{S I I}$ mapped on LG4. In addition, quantitative resistance models were also proposed (Louarn et al., 2016; Akhtouch et al., 2016). Pérez-Vich et al. (2004) suggested that broomrape resistance might be controlled through both qualitative race-specific and quantitative non-race specific components. The lack of consensus in results might be due to differences in the race groups, resistance sources (donor parents) and recipient parents used in the previous studies. Although segregation of the trait in the present study suggested complementary gene action, logarithmic transformation of the phenotypic data displayed continuous variation indicating that broomrape resistance is a quantitative trait in sunflower.

\section{QTL mapping}

A high density GBS derived SNP based map was used for QTL mapping of broomrape race F resistance for the first time. As a result, three new QTLs for race F resistance were identified. The present study showed that resistance is controlled by major QTLs with PVEs of 41 to $49 \%$ in contrast to previous studies which reported QTLs with lesser effects (9 to 39\%). However, previous studies used low resolution maps which may have limited their ability to estimate PVE (Perez-Vich et al., 2004; Louarn et al., 2016; Akhtouch et al., 2016).

CAPS markers for verification of the QTLs were developed. Testing of these markers in the resistant individuals of an $\mathrm{F}_{6}$ population showed that at least one QTL was enough for conferring partial resistance (in 40 plants of the 43 plants; 93\%) and to prevent parasite infection. The SNP based CAPS assays developed in this work can be used for marker assisted selection for breeding of sunflower cultivars resist to broomrape.

\section{Annotation of QTLs}

Although two candidate genes (RSG3-301 and HaGSL1) were reported to be involved in host plantparasitic weed interactions, the molecular genetic bases of these interactions have not been clearly elucidated ( $\mathrm{Li}$ and Timko, 2009). HaGSL1 (H. annuus glucan synthase-like) is a member of the callose synthase gene family, and was first reported to be involved in defense against $O$. cumana in sunflower by Letousey et al. (2007). These researchers showed that host plant-broomrape interaction resulted in HaGSL1 overexpression and callose accumulation in resistant genotypes. The other candidate gene, RSG3-301 was first identified in cowpea against the parasite Striga gesnerioides ( $\mathrm{Li}$ and Timko, 2009). 
Table 1. QTLs identified for broomrape race F resistance in sunflower and QTL specific CAPS markers.

\begin{tabular}{|c|c|c|c|c|c|c|c|c|c|c|c|c|}
\hline QTL & LG & Position (Mb) $)^{a}$ & Position $(\mathrm{cM})^{\mathrm{b}}$ & Marker interval & LOD & $\mathbf{P V E}^{\mathrm{c}}$ & Additive effect $^{d}$ & CAPS primers & Enzyme & $\begin{array}{l}\begin{array}{l}\text { Pcr } \\
\text { product } \\
(\mathbf{R} / \mathbf{S})\end{array} \\
\end{array}$ & Allele & Position \\
\hline or.7.1 & LG7 & $126-128.2$ & $40.1-43.9$ & $\begin{array}{l}\text { HaSNP_GBS121407884: } \\
\text { GBS128768454 }\end{array}$ & 12.3 & 45 & cv. H08 M1 & $\begin{array}{l}\text { F:AAATGTTCACACTAACGGTATTC } \\
\text { R:GTCAAATCATAAACAAACAACAA }\end{array}$ & $\begin{array}{l}\text { BsaWI/ } \\
\text { MspI }\end{array}$ & $90 / 100$ & $\mathrm{G} / \mathrm{C}$ & 130635552 \\
\hline or11.1 & LG11 & $153.1-154.9$ & 64.3 & $\begin{array}{l}\text { HaSNP_GBS153744997: } \\
\text { GBS155889170 }\end{array}$ & 13 & 49 & cv. H08 M2 & $\begin{array}{l}\text { F:TTAGGAGTAGTGCCGTTAAGAC } \\
\text { R:CATAAACCAACAACACATGATTA }\end{array}$ & Hpy188III & $40 / 90$ & $\mathrm{G} / \mathrm{C}$ & 156955897 \\
\hline or 12.1 & LG12 & $139-142$ & $36-37.3$ & $\begin{array}{l}\text { HaSNP_GBS139054720: } \\
\text { GBS142192138 }\end{array}$ & 10 & 41 & cv. H08 M3 & $\begin{array}{l}\text { F:GATATCGCAGCCATCAGAGT } \\
\text { R:ACCTAGGGTCATACCCATGC }\end{array}$ & HincII & $110 / 70$ & $\mathrm{~T} / \mathrm{C}$ & 140903756 \\
\hline
\end{tabular}

Peak position of QTL based on physical map

${ }^{c}$ Percentage of phenotypic variation explained by $Q T L$

${ }^{c}$ Percentage of phenotypic variation explained by QTL
Parental allele associated with increased resistance score 
Table 2. Results of CAPS assays for the three QTLs performed on resistant individuals of the $\mathrm{F}_{6}$ population. R: resistance allele, S: susceptible allele, H: Heterozygote and X: missing data.

\begin{tabular}{|c|c|c|c|c|c|c|c|c|c|}
\hline Plant & $\begin{array}{c}\mathbf{R} \\
\text { assay }\end{array}$ & $\begin{array}{c}\text { HaSNP }_{-} \\
\text {GBS } \\
1306355 \\
52\end{array}$ & $\begin{array}{c}\text { HaSNP_ } \\
\text { GBS } \\
1569558 \\
97\end{array}$ & $\begin{array}{c}\text { HaSNP }_{-} \\
\text {GBS } \\
1409037 \\
56\end{array}$ & Plant & $\begin{array}{c}\mathbf{R} \\
\text { assay }\end{array}$ & $\begin{array}{c}\text { HaSNP }_{-} \\
\text {GBS } \\
1306355 \\
52\end{array}$ & $\begin{array}{c}\text { HaSNP }_{-} \\
\text {GBS } \\
1569558 \\
97\end{array}$ & $\begin{array}{c}\text { HaSNP_ } \\
\text { GBS } \\
1409037 \\
56\end{array}$ \\
\hline $\begin{array}{l}\text { H08 M1 } \\
\text { (Resistant ) }\end{array}$ & $\mathrm{R}$ & $\mathrm{R}$ & $\mathrm{R}$ & $\mathrm{R}$ & F6.23 & $\mathrm{R}$ & $S$ & $\mathrm{R}$ & S \\
\hline $\begin{array}{l}\text { RHA } 436 \\
\text { (Susceptible } \\
\text { ) }\end{array}$ & $\mathrm{S}$ & $S$ & $\mathrm{~S}$ & $S$ & F6.24 & $\mathrm{R}$ & $\mathrm{R}$ & $\mathrm{S}$ & $S$ \\
\hline F6.1 & $\mathrm{R}$ & $\mathrm{R}$ & S & $\mathrm{R}$ & F6.25 & $\mathrm{R}$ & S & $\mathrm{R}$ & S \\
\hline F6.2 & $\mathrm{R}$ & $\mathrm{S}$ & S & $\mathrm{R}$ & F6.26 & $\mathrm{R}$ & S & $\mathrm{R}$ & S \\
\hline F6.3 & $\mathrm{R}$ & S & $\mathrm{R}$ & S & F6.27 & $\mathrm{R}$ & S & $\mathrm{R}$ & S \\
\hline F6.4 & $\mathrm{R}$ & $\mathrm{R}$ & $\mathrm{S}$ & S & F6.28 & $\mathrm{R}$ & S & $\mathrm{R}$ & S \\
\hline F6.5 & $\mathrm{R}$ & S & S & $\mathrm{R}$ & F6.29 & $\mathrm{R}$ & S & $\mathrm{S}$ & $\mathrm{R}$ \\
\hline F6.6 & $\mathrm{R}$ & $S$ & S & S & F6.30 & $\mathrm{R}$ & $\mathrm{R}$ & S & S \\
\hline F6.7 & $\mathrm{R}$ & $\mathrm{R}$ & S & S & F6.31 & $\mathrm{R}$ & $\mathrm{R}$ & S & S \\
\hline F6.8 & $\mathrm{R}$ & $\mathrm{S}$ & S & $\mathrm{R}$ & F6.32 & $\mathrm{R}$ & $\mathrm{R}$ & S & S \\
\hline F6.9 & $\mathrm{R}$ & $X$ & $\mathrm{R}$ & $\mathrm{R}$ & F6.33 & $\mathrm{R}$ & $\mathrm{R}$ & $\mathrm{S}$ & S \\
\hline F6.10 & $\mathrm{R}$ & $\mathrm{S}$ & $\mathrm{R}$ & S & F6.34 & $\mathrm{R}$ & $\mathrm{R}$ & $\mathrm{R}$ & S \\
\hline F6.11 & $\mathrm{R}$ & $\mathrm{S}$ & S & S & F6.35 & $\mathrm{R}$ & $\mathrm{R}$ & $S$ & S \\
\hline F6.12 & $\mathrm{R}$ & $\mathrm{H}$ & $\mathrm{R}$ & $S$ & F6.36 & $\mathrm{R}$ & $S$ & $\mathrm{R}$ & $S$ \\
\hline F6.13 & $\mathrm{R}$ & $\mathrm{S}$ & $\mathrm{R}$ & S & F6.37 & $\mathrm{R}$ & $\mathrm{R}$ & $S$ & $\mathrm{R}$ \\
\hline F6. 14 & $\mathrm{R}$ & $\mathrm{S}$ & $\mathrm{R}$ & $S$ & F6.38 & $\mathrm{R}$ & $S$ & $\mathrm{R}$ & $\mathrm{R}$ \\
\hline F6.15 & $\mathrm{R}$ & $S$ & $\mathrm{R}$ & S & F6.39 & $\mathrm{R}$ & $\mathrm{R}$ & $\mathrm{S}$ & $\mathrm{R}$ \\
\hline F6.16 & $\mathrm{R}$ & $\mathrm{R}$ & $\mathrm{S}$ & $\mathrm{R}$ & F6.40 & $\mathrm{R}$ & $\mathrm{R}$ & $\mathrm{S}$ & $\mathrm{R}$ \\
\hline F6.17 & $\mathrm{R}$ & $\mathrm{R}$ & $\mathrm{S}$ & $\mathrm{S}$ & F6.41 & $\mathrm{R}$ & $\mathrm{R}$ & $S$ & $\mathrm{R}$ \\
\hline F6.18 & $\mathrm{R}$ & $\mathrm{S}$ & $\mathrm{R}$ & $S$ & F6.42 & $\mathrm{R}$ & $\mathrm{R}$ & $\mathrm{S}$ & $\mathrm{R}$ \\
\hline F6.19 & $\mathrm{R}$ & $\mathrm{R}$ & $\mathrm{S}$ & $S$ & F6.43 & $\mathrm{R}$ & $\mathrm{R}$ & $\mathrm{R}$ & $\mathrm{R}$ \\
\hline F6.20 & $\mathrm{R}$ & $\mathrm{S}$ & $\mathrm{S}$ & $S$ & & & & & \\
\hline F6.21 & $\mathrm{R}$ & $\mathrm{S}$ & $\mathrm{R}$ & $S$ & & & & & \\
\hline F6.22 & $\mathrm{R}$ & $S$ & $\mathrm{R}$ & $S$ & & & & & \\
\hline
\end{tabular}

tructure (CC-NBS-LRR) of the gene was predicted and it was proposed that the protein is involved in an incompatible attachment between host and pest which leads to resistance. Louarn et al. (2016) performed QTL annotation for homologs of the RSG3-301 gene in sunflower and found that three RSG3-301 gene homologs localized with QTLs identified for control of broomrape field emergence, induction of incompatible attachment and induction of necrotic tubercles on LG13, 15 and 17, respectively. However, they could not map HaGSL in their study.

Candidate resistance genes in the QTL regions were identified in the present study; however, only one QTL (or7.1) region contained a known disease related gene: the LURP-one-related 10-like gene (Knoth and Eulgem, 2008) which is a member of the LURP (late upregulated in response to Hyaloperonospora parasitica)-one related (LOR) gene family. Although its mechanism has not been completely clarified, the LURP1 gene is necessary for the basal defense mechanism to $H$. parasitica, an oomycete. In the present study, the absence of any homologs of the previously identified candidate genes (RSG3-301 and HaGSL1) in the QTL regions indicates that the molecular mechanism of broomrape resistance in sunflower requires further study.
The present study identified three major QTLs for broomrape race $F$ resistance in sunflower using GBS derived SNP markers for the first time. Breeder-friendly QTL specific SNP based CAPS assays were developed and show that the presence of at least one QTL was essential for conferring partial resistance. The identified QTLs and linked CAPS markers are valuable tools for marker assisted selection in breeding for race $\mathrm{F}$ resistance in sunflower.

\section{ACKNOWLEDGMENTS}

This study was supported by grant 5130037 from the Scientific and Technological Research Council of Turkey (TUBITAK).

\section{AUTHOR CONTRIBUTIONS}

AAB drafted and revised manuscript; IC generated molecular data, analyzed all data, and drafted manuscript; $\mathrm{CD}$ did parasite testing; $\mathrm{AF}$ and SD conceived of project and revised manuscript, SD obtained funding.

\section{LITERATURE CITED}

Akhtouch, B., L. Del Moral, A. Leon, L. Velasco, J.M. Fernández-Martínez and B. Pérez-Vich. 2016. Genetic study of recessive broomrape resistance in sunflower. Euphytica 209: 419-428. 
Akhtouch, B., J. Muñoz-Ruz, J. Melero-Vara, J. FernándezMartínez and J. Domínguez. 2002. Inheritance of resistance to race $\mathrm{F}$ of broomrape in sunflower lines of different origins. Plant Breed. 121: 266-268.

Bulbul, A., M. Salihoglu, C. Sari and A. Aydin. 1999. Determination of broomrape (Orobanche cumana Wallr.) races of sunflower in the Thrace region of Turkey. Helia. 14:21-26.

Celik, I., S. Bodur, A. Frary and S. Doganlar. 2016a. Genomewide SNP discovery and genetic linkage map construction in sunflower (Helianthus annuus L.) using a genotyping by sequencing (GBS) approach. Mol. Breed. 36: 133.

Celik, I., M.A. Sogut, E. Ozkaynak, S. Doganlar and A. Frary 2016b. Physical mapping of NBS-coding resistance genes to the Me-gene cluster on chromosome P9 reveals markers tightly linked to the $\mathrm{N}$ gene for root-knot nematode resistance in pepper. Mol Breed. 36(10): 137.

Churchill, G.A. and R.W. Doerge. 1994. Empirical threshold values for quantitative trait mapping. Genetics. 138: $963-$ 971.

Conesa, A., S. Gotz, J.M. García-Gómez, J. Terol, M. Talón and M. Robles. 2005. Blast2GO: a universal tool for annotation, visualization and analysis in functional genomics research. Bioinformatics 21: 3674-3676.

Cvejić, S., A. Radanović, B. Dedić, M. Jocković, S. Jocić and D. Miladinović. 2020. Genetic and genomic tools in sunflower breeding for broomrape resistance. Genes. 11: 152.

Dong, Q., S.D. Schlueter and V. Brendel. 2004. PlantGDB, plant genome database and analysis tools. Nucleic Acids Res. 32: 354-359.

Duriez, P., S. Vautrin, M.C. Auriac, J. Bazerque, M.C. Boniface, C. Callot, S. Carrère, S. Cauet, M. Chabaud, F. Gentou, M. Lopez-Sendon, C. Paris, P. Pegot-Espagnet, J.C. Rousseaux, B. Pérez-Vich, L. Velasco, H. Bergès, J. Piquemal and S. Muños. 2019. A receptor-like kinase enhances sunflower resistance to Orobanche Cumana. Nat. Plant. 5: 1211.

Fernández-Martínez, J., B. Pérez-Vich, B. Akhtouch, L. Velasco, J. Muñoz-Ruz, J.M. Melero-Vara and J. Domínguez. 2004. Registration of Four Sunflower Germplasms Resistant to Race F of Broomrape. Crop Sci. 44: 1033-1034.

Grenz, J., V. Ikstoc, A. Manschadi and J. Sauerborn. 2008. Interactions of sunflower (Helianthus annuus) and sunflower broomrape (Orobanche cumana) as affected by sowing date, resource supply and infestation level. Field Crops Res. 107: 170-179.

Imerovski, I., A. Dimitrijević, D. Miladinović, B. Dedić, S. Jocić, N.K. Tubić and S. Cvejić. 2016. Mapping of a new gene for resistance to broomrape races higher than $\mathrm{F}$. Euphytica 209: 281-289.

Joehanes, R. and J.C. Nelson. 2008. QGene 4.0 an extensible Java QTL-analysis platform. Bioinformatics 24: 2788-2789.

Kaya, Y., G. Evci, V. Pekcan and T. Gucer. 2004. Determining new broomrape-infested areas, resistant lines and hybrids in Trakya region in Turkey. Helia. 40: 211-218.

Knoth, C. and T. Eulgem. 2008. The oomycete response gene LURP1 is required for defense against Hyaloperonospora parasitica in Arabidopsis thaliana. Plant J. 55(1): 53-64.

Letousey, P., A. De Zélicourt, C. Vieira Dos Santos, S. Thoiron, F. Monteau, P. Simier, P. Thalouarn and P. Delavault. 2007. Molecular analysis of resistance mechanisms to Orobanche cumana in sunflower. Plant Pathol. 56: 536-546.

Li, J. and M.P. Timko. 2009. Gene-for-gene resistance in Strigacowpea associations. Science. 325: 1094-1094.

Louarn, J., M.C. Boniface, N. Pouilly, L. Velasco, B. PérezVich, P. Vincourt and S. Muños. 2016. Sunflower resistance to broomrape (Orobanche cumana) is controlled by specific QTLs for different parasitism stages. Front. Plant Sci. 7: 590.
Martín-Sanz, A., J. Malek, J.M. Fernández-Martínez, B. PérezVich and L. Velasco. 2016. Increased virulence in sunflower broomrape (Orobanche cumana Wallr.) populations from Southern Spain is associated with greater genetic diversity. Front. Plant Sci. 7: 589.

Martin-Sanz, A., B. Perez-Vich, S. Rueda, J.M. FernandezMartinez and L. Velasco. 2020. Characterization of posthaustorial resistance to sunflower broomrape. Crop Sci. 60: $1188-1198$

Molinero-Ruiz, L., A.B. Garcia-Carneros, M. Collado-Romero, S. Raranciuc, J. Dominguez and M. Melero-Vara. 2014. Pathogenic and molecular diversity in highly virulent populations of the parasitic weed Orobanche Cumana (sunflower broomrape) from Europe. Weed Res. 54: 87-96.

Pérez-Vich, B., B. Akhtouch, S.J. Knapp, A.J. Leon, L. Velasco, J.M. Fernández-Martínez and S.T. Berry. 2004. Quantitative trait loci for broomrape (Orobanche cumana Wallr.) resistance in sunflower. Theor. Appl. Genet. 109: 92-102.

Velasco, L., B. Pérez-Vich, C.C. Jan and J.M. FernándezMartínez. 2007. Inheritance of resistance to broomrape (Orobanche cumana Wallr.) race $\mathrm{F}$ in a sunflower line derived from wild sunflower species. Plant Breed. 126: 6771.

Vranceanu, A.V., N. Pirvu, F.M. Stoenescu and M. Pacureanu. 1986. Some aspects of the interactions Helianthus annuus L./Orobanche cumana Wallr. and its implications in sunflower breeding. pp: 181- 189. In S.J. ter Borg (ed.) Biology and control of Orobanche: Proc. Workshop in Wageningen, The Netherlands. Wageningen Agric Univ, Wageningen.

You, F.M., N. Huo, Y.Q. Gu, M.C. Luo, Y. Ma, D. Hane, G.R. Lazo, J. Dvorak and O.D. Anderson. 2008. BatchPrimer3: a high through-put web application for PCR and sequencing primer design. BMC Bioinformatics. 9: 2. 